\title{
MEMORIAL ACADÊMICO*
}

http://dx.doi.org/10.11606/issn.2237-1184.v0i33p132-152

João Luiz Lafetá ${ }^{\mathrm{I}}$

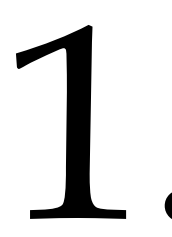

\section{Montes Claros. Família. Primário. Ginásio}

Minas. Na minha infância era uma cidade sertaneja, entreposto comercial e centro de vasta região agropecuária. Poucas ruas calçadas com pé-de-moleque, carros de boi, carroças, cavaleiros, alguns automóveis, muita poeira vermelha e o calor de até hoje.

Leio que o censo de 50 atribuiu ao município a população de 72.557 habitantes. Vejo, também, que por volta de 1955, essa cifra se elevava para 81.710 habitantes, sendo cerca de 30 mil na cidade e o restante nos distritos. Os números me parecem altos. Minha lembrança é de uma comunidade pequena, onde as pessoas se conheciam todas pelos nomes de família e se relacionavam cordialmente - apenas divididas pela rivalidade política entre PSD e PR, sempre disputando a prefeitura. Visão de classe média, talvez, ignorante, dos lavradores e vaqueiros que, já naquela época, abandonavam as fazendas próximas, o sertão baiano e o nordeste, e iam se aglomerando em torno da cidade.

São meus pais José Carlos Lafetá e Maria da Conceição Machado Lafetá. Meu pai fez o curso secundário e iniciou os preparatórios, mas teve de abandonar os estudos para trabalhar. Foi bancário, depois empregado na casa comercial de um tio, e em seguida estabeleceu-se por conta própria. Negociante á moda antiga, apegado à limpidez das transações, abominando a especulação e o lucro excessivo, nunca enriqueceu. Há poucos anos vendeu a loja e empregou-se nos escritórios de uma indústria,

* Apresentado para concurso de efetivação como professor no DTLLC, onde já vinha trabalhando desde 1978. Originalmente publicado na revista Literatura e Sociedade, n. 3, São Paulo, 1998. DOI: https:// doi.org/10.11606/issn.2237-1184.v0i3p85-99

I Universidade de São Paulo, São Paulo, São Paulo, Brasil. 
onde trabalha ainda hoje. Minha mãe estudou música e formou-se como professora de piano mas durante anos dedicou-se apenas às (muitas) tarefas de dona de casa. Mais tarde passou a lecionar no centro de Estadual de Artes Lorenzo Fernandez, em Montes Claros, onde também ainda trabalha, professora e funcionária pública.

Somos cinco irmãos, dos quais o mais velho sou eu. Em nossa educação, meus pais sempre valorizam os estudos, a "cultura" - em detrimento do dinheiro, que é exterior e não constitui propriamente a pessoa. Faziam apologia do trabalho e da pobreza honrada; que não se curva aos poderosos e nem se arroga direitos sobre os outros. Foi uma educação meio espartana, do tipo bastante comum no interior do Brasil, naquela época e naquele meio social: muitas as obrigações, poucos os prazeres e tudo o dever. A ideologia da escola reforçava essas noções, estendendo-as até a pátria, é claro. Demorei a descobrir que as coisas são pouco mais complicadas. Digo isso porque penso ter introjetado de tal modo esses ensinamentos que - malícias a parte - continuo acreditando neles. Coisa que às vezes me deixa meio desarmado, também intelectualmente.

Comecei o curso primário, no Grupo Escolar Gonçalves Chaves, em 1953. Escola Tradicional: professoras severas e disciplinadoras; alfabetização no livro Lili, Lalau e o Lobo; hora cívica; comemorações em que se recitava poesia (13 de Maio: "Caminhoneiro que passas pela estrada,/ Seguindo pelo rumo do sertão" ...); tabuada cantada, aula de Ciências em que se estudava o esqueleto de uma galinha, a germinação do feijão; História de Minas, assombros e anedotas (Chica da Silva, o Aleijadinho, a Inconfidência), de Montes Claros e do Brasil; redações inspiradas por gravuras que mostravam crianças rosadas, à beira de um riacho límpido, tendo ao fundo um moinho, pretexto para se falar de uma Holanda fantástica, aula de Geografia. Fui bom aluno, cadernos em ordem, deveres feitos, primeiro da classe. Sem saber, pastichava a prosa de Alencar, modelos vindos não sei de onde. O mais constante era o capítulo VII de $O$ guarani: "A tarde ia morrendo.// O sol declinava no horizonte e deitavase sobre as grandes florestas, que iluminava com seus últimos raios". Concluí em 1956.

1957: curso de Admissão no Ginásio São José, recém-fundado em Montes Claros pelos Irmãos Maristas. Alegavam que o primário da cidade era fraco e que precisavam de um ano para "dar base" aos alunos e permitilhes fazer o ginásio. E estavam certos. No começo eram apenas três, excelentes professores, cuidadosos, capazes de acompanhar cada um de nós dia a dia, inteiramente dedicados - coisa que nunca mais vi, em escola nenhuma. Formavam de verdade, embora dentro de um sistema cujos defeitos são hoje muito evidentes: o hábito de decorar sem compreender, o estímulo à competição através de prêmios, a cópia de modelos. Foi assim 
que, no decorrer do ginásio, de 1958 a 1961, decorei as declinações e as conjugações do latim, traduzi Fedro e César, verti pequenos textos do português. Decorei também infindáveis relações de países, suas populações e suas capitais, além de nomes de rios brasileiros, afluentes principais das duas margens, montanhas e pontos de extrema altitude, produção econômica de cada região, tipo de flora e fauna, variações climáticas. Decorei, ainda, regras de Gramática da Língua Portuguesa, verbos franceses, capítulos inteiros de história do Brasil, teoremas, poemas, trechos antológicos, lições de religião, etc. Competi e ganhei as medalhas de praxe. Firmei o hábito de seguir os modelos.

Suponho que tudo isso tenha também o seu lado positivo. Adquiri a tal "base" que os maristas prezavam tanto. Indo estudar mais tarde em Belo Horizonte, não tive dificuldade para acompanhar os cursos. Mas a importância que vejo nesse ginasial está menos na quantidade de matéria decorada com assimilação mínima, do que em certos hábitos de trabalho intelectual que aprendi com um daqueles professores. Acho que "rigor" e "clareza", sem as conotações cientificistas que essas palavras adquiriram nos últimos anos, servem para definir o que eu tenho em mente. E que é simples: enfrentar os problemas de maneira metódica, caminhado do elementar ao mais complexo sem queimar etapas, explicando todas as passagens e recusando-se a encobrir as dificuldades e os pontos desconhecidos.

Sei como essa atitude pode transforma-se em esquematismo simplificador e tedioso. Mas não via isso nas aulas do irmão Leonardo, o professor a quem me referi. Era um homem franzino, precocemente careca, mais ainda muito jovem e dotado de energia incrível. Jogava futebol e ensinava com o mesmo vigor e habilidade. Era respeitado (e mesmo amado) pelos alunos, aos quais tratava com senso de justiça e rara acuidade psicológica. Esteve três anos no ginásio (57-59), e depois nunca mais o vi. Hoje, entretanto, descubro que o meu modo de lecionar é um pouco moldado pelo dele, e mesmo a minha letra (que é péssima) tem algo do talho da letra dele (que era ótima).

Desejo falar um pouco de duas atividades não escolares a que me dediquei bastante nessa época. Gostava de ler romances e lia muito, trocando com frequência o bando de amigos adolescentes por horas de leitura, em casa ou na Biblioteca Municipal. Na infância foi Monteiro lobato (aprendido quase de cor), Viriato Correia, uma história de Graciliano Ramos, Grimm e Perrault, uma série de biografias de músicos escritos para crianças. Na adolescência foi o que caísse nas mãos: Érico Veríssimo e Jorge Amado inteiros, José Lins do Rego, capa-e-espada (havia uma coleção chamada Terra-Mar-e-Ar - não me lembro mais como se escrevia), seleções do Reader's Digest, Machado de Assis e José de Alencar, romances policiais, uma coleção dos Prêmios Nobel, a coleção saraiva, Dickens etc. Poesia era 
ainda a romântica e a parnasiana, com um pouquinho de Drummond ou Bandeira, catados aqui e ali. (Recitava-se "José", naturalmente.) Enfim, a infusão que também deve ser banal, mas que assinalo por achá-la decisiva para os rumos que a minha vida foi tomando.

No outro ponto, também banal e (para mim), importante, serei breve: por volta de 1960-61 comecei a participar do movimento estudantil. Fui fundador e presidente do grêmio do Ginásio, secretário do Diretório dos Estudantes de Montes Claros, membro ativo da Juventude Estudantil Católica. Tomei conhecimento dos movimentos sociais, discuti a Lei de Diretrizes e Bases da educação Nacional, fiquei sabendo de Cuba, habitueime a acompanhar, dia a dia, o noticiário político dos jornais. Essa militância continuaria nos anos seguintes.

\section{Belo Horizonte. Científico. Clássico}

Em 1962 mudei-me para Belo Horizonte, a fim de continuar os estudos. Tinha Vontade de fazer o clássico, dirigido para as humanidades, mas meus pais achavam que o científico daria mais... "base" para qualquer futura carreira. E como eu oscilasse sempre entre Jornalismo e Geologia (havia um curso famoso em Ouro Preto, a profissão tinha prestígio e a influência de Monteiro Lobato ainda era marcante), decidiram por mim e mandaram-me para o Colégio Santo Antônio, dirigido por frades franciscanos e um dos melhores do estado.

O Santo Antônio fica no bairro do mesmo nome, na rua Santa Rita Durão, quase esquina com Pernambuco. Nessa última, dando fundos para o colégio, ficava o pensionato dos padres, onde iam morar os estudantes vindos do interior. Era um prédio longo, de dois andares, com quartos individuais ou para duas pessoas, um refeitório amplo, um pequeno jardim e uma piscina. O regime era de semi-internato. De manha íamos para as aulas, depois do almoço havia descanso, das duas às cinco era o período de estudo, depois piscina, jantar e noite livre. $\mathrm{O}$ portão fechava às vinte e duas horas (nos sábados às vinte e três), e permitia-se passar os fins de semana com os parentes. O clima era de liberdade - uma espécie de modernização dos conhecidos internatos mineiros, cujo paradigma foi o Caraça.

O colégio era puxado. No primeiro ano, tínhamos aulas de Matemática, Física, Química, Português, Inglês e História (além da hora semanal de Religião, em que Frei Chico, holandês se sotaque terrível, aborrecia todo mundo falando sobre problemas da juventude). As três primeiras disciplinas eram o forte da escola; as três últimas eram fraquíssimas. Mas no geral exigia-se muito, e as três horas diárias de estudo obrigatório nem sempre eram suficientes. Em véspera de prova ninguém saía a noite, revendo a matéria até o toque de recolher. 
Desempenhei-me bem, com boas notas. Mas descobri que preferia o clássico, e seguiria uma carreira na área de Humanas. Direito, Jornalismo ou Ciências Sociais? Não sabia. No fim doa no fiz um teste vocacional (novidade em Belo Horizonte), mas o resultado deixou-me na mesma perplexidade: tinha inclinações para Direito, Jornalismo e Ciências Sociais. Bom.

Saí do Santo Antônio e fui para o Colégio Estadual de Minas Gerais, em 1963. Foi fácil convencer meus pais, pois o ensino público era considerado ótimo, e além do mais era gratuito (a inflação do governo João Goulart ia diminuindo os recursos da pequena classe média). Fiz o concurso de ingresso (uma redação) e fui aprovado em primeiro lugar. Decidi estudar à noite e trabalhar em um jornal durante o dia. Mas o emprego ficou apenas no projeto.

O ensino Público não era bom, já começava a decadência que iria leva-lo ao estado de hoje. O período noturno seria o pior. Os professores também já eram mal pagos, e lembro-me de uma greve (vitoriosa) por salários e vantagens, no final de 63. No segundo clássico, o professor de História aparecia uma vez por bimestre, divertia-nos com a sua conversa viva e inteligente, e mandava-nos ler e resumir um livro para a nota do bimestre seguinte. Lembro-me de ter lido assim Reforma ou Revolução?, de Franklin de Oliveira, Aspirações nacionais, de José Honório Rodrigues, e um livro sobre a revolução cubana, creio que de Paul Sweezy e Leo Huberman. Como se vê, se não era bom, talvez não fosse de todo mau. A época ajudava muito, estimulando a discussão.

Estudávamos ainda Latim (trabalhosas traduções de Vergílio - que esqueci), Espanhol, Francês, Psicologia, Filosofia e Português. Dois professores foram marcantes. José de Anchieta, católico, lecionava Filosofia. Líamos e fichávamos cuidadosamente a Introdução a Filosofia, de Julían Marías, discípulo de Ortega y Gasset, discutindo a "crise do mundo contemporâneo". Mas Anchieta era militante e da esquerda católica, trabalhava nos movimentos de educação de base e falava-nos de Paulo Freire, alfabetização, conscientização, política. Depois de 64 foi perseguido, afastou-se por uns meses e retornou na mesma batida - o que despertava a nossa admiração.

Iraci era professora de Português. Paulista, formada em Assis, dispensou o compêndio tradicional e remeteu-nos diretamente aos livros e às histórias literárias. Lembro-me de suas primeiras aulas, sobre o tema "o que é literatura": a definição em sentido lato, que englobava mesmo as obras ensaísticas; a definição em sentido estrito, que reduzia a literatura às obras de imaginação e ao lirismo; a definição estética, que partia da linguagem e de sua realização. (Revolvo o problema até hoje.)

Li muito nesses dois anos. No meio da adolescência, como todo mundo, descobri Fernando Pessoa. E apaixonei-me pela poesia de 
Drummond, Bandeira, Vinícius, Cecília Meireles e até de Augusto Frederico Schmidt (mais tarde renegada). Tendo o dia todo livre, retomei todos os romances: Balzac, Stendhal, Flaubert, Zola, Tolstoi, Dostoiévsky, Gogol, Gorki - encontrava a grande literatura realista. Também os contemporâneos que eram moda e tema de discussão nas rodinhas belohorizontinas: o romance e o teatro político de Sartre, Simone de Beauvoir, Beckett, Kafka, Ionesco.

Essas leituras somavam-se aos filmes, à nouvelle-vague francesa, ao neo-realismo italiano, ao cinema-novo que começava e sobretudo a Fellini e à trilogia de Antonioni. Existencialismo, disponibilidade, gratuidade, liberdade, opção eram termos de uso corrente, reconheço que bem degradados. Mas era o ambiente do tempo, na Belo Horizonte pequenoburguesa e acanhada, cidade funcionários públicos que começava a crescer.

E era tempo também de introdução ao marxismo. Lembro-me de ter lido o Manifesto e o manual de Georges Politzer, de ter folheado Engels e Lenin, e de ter espiado sem coragem a tradução espanhola de O Capital. A agitação de 63 foi enorme, e expressões como materialismo histórico, materialismo dialético, luta de classes, povo e revolução circulavam, igualmente degradadas, nas conversas dos colégios e dos bares. Líamos os Cadernos do Povo Brasileiro, acompanhávamos O CPC da UNE. O golpe de 64 só arrefeceu num primeiro momento o debate. Logo depois as edições do Correio da Manhã esgotavam-se nas bancas de Belo Horizonte, procuradas por leitores ávidos da resistência empreendida por Carpeaux, Cony, Hermano Alves, Márcio Moreira e Tristão de Ataíde (esse no Jornal do Brasil).

Em fins de 64 terminei o clássico e decidi-me: nem Direito, nem Jornalismo, nem Ciências Sociais. Faria Letras, na Universidade de Brasília.

\section{Universidade de Brasília}

Resolvi estudar Letras por um motivo apenas: gostava de literatura. Pensava ainda, persistindo no plano antigo, em profissionalizar-me como jornalista, embora não quisesse fazer o curso de Comunicações. Entre 63 e 64 havia trabalhado vários meses, durante as férias, n’O Jornal de Montes Claros, primeiro redigindo a página policial, e mais tarde sendo designado pelo secretário para escrever as notícias locais. Gostara do Trabalho e tinha intenção de continua-lo, mas o desejo de estudar Literatura era maior. E assim cheguei a solução de compromisso: faria Letras e tentaria empregarme num jornal, em Brasília.

E por que lá? Conheci Brasília em 1960, antes da sua inauguração. Muitos dos meus tios e primos eram pioneiros dos primeiros tempos e falavam com entusiasmo da cidade. Entusiasmei-me também. Depois de 
três anos, Belo Horizonte parecia-me já conhecida, sem nada de novo para mostrar. O novo estava na Universidade de Brasília, com seus institutos e departamentos, seu campus diferente permitindo o convívio interdisciplinar, seus professores revolucionários. Era invenção do montesclarense Darcy Ribeiro, que rebentara com essa experiência a estrutura universitária antiquada das Faculdades estanques, dominadas por catedráticos. O novo estava nascendo na UnB - dizia-se.

Acreditei e fui para lá. Fiz o vestibular em 1965, aprovado com a segunda colocação. Comecei o curso.

Era novo, mesmo; e o primeiro semestre de 65 foi muito rico. No meu curso, estava matriculado em três disciplinas apenas: Literatura Brasileira, Literatura Portuguesa e Língua Inglesa. Se não eram excelentes, pelo menos eram interessantes. Lembro-me de que o curso de Literatura Brasileira, dado pelo Prof. Luís Geraldo Toledo Machado, era um panorama do nosso romance. Estudamos Manuel Antônio de Almeida, Alencar, Machado e, se não me engano, Raul Pompéia. Para cada autor eram relacionados alguns textos críticos, que líamos e discutíamos em aula.

Literatura Portuguesa era também panorâmico: começava com os cronistas, passava por Gil Vicente e Camões, pelo Romantismo e pelo Realismo, e terminava com Fernando Pessoa. Tinha um alinha doutrinária clara, o sebastianismo messiânico, pregado pelo titular da disciplina, Prof. Agostinho da Silva - Ideólogo de uma Comunidade Internacional de Língua Portuguesa, sucedânea do V Império. Apesar da extravagância (ou por causa dela, não sei), Agostinho da Silva era um professor fascinante, capaz de prender nossa atenção horas a fio, pulando de Fernão Lopes a Vieira, de Fernão Mendes Pinto a Herculano, de Fernando Pessoa a Glauber Rocha e ao sertão brasileiro.

A riqueza de informações novas, entretanto, estava mais nas atividades do campus do que nas aulas regulares. Havia um curso chamado apreciação cinematográfica, que ia nos ensinando, através dos filmes exibidos, um pouco da história do cinema. Antes da exibição um professor falava explicando e situando a fita. Revezavam-se Paulo Emílio Salles Gomes e Lucilla Ribeiro Bernadet. Havia concertos musicais nas manhãs de sábado, no pequeno auditório de música, que ficava lotado. Pela primeira vez ouvi as dissonâncias da música contemporânea. E havia também conferências extra-programa, sempre com salas cheias. E alunos vindo de todos os lugares do Brasil, fazendo cursos diferentes, trocando experiências. O campus era muito vivo.

No segundo semestre houve a conhecida crise da Universidade, que resultou no pedido de demissão de cento e tantos professores e no fim do projeto inicial da UnB. Acompanhei os fatos atentamente, participando de assembleias e reuniões. No final, a Polícia Militar fechou o campus e as aulas foram suspensas. Íamos até as barreiras policiais e ficávamos parados, 
conversando sobre aquilo. Para nós, era uma experiência forte. E no protesto que os estudantes organizaram na Estação Rodoviária, bobeei, fui detido. Solto horas depois.

As aulas se reiniciaram, improvisadas, com professores contratados de qualquer maneira. Em 1966 o clima era o oposto ao do ano anterior: desânimo geral, nenhuma atividade, nenhuma atividade, nenhuma vida. Comecei a fazer política estudantil, parecia muito necessário. A Federação dos Estudantes da Universidade de Brasília (FEUB) tinha sido desorganizada durante a crise e precisava ser reconstruída. Organizou-se uma chapa única, deram-me o cargo de secretário. A partir daí, e até o fim do curso, estive envolvido no movimento estudantil, que me tomou um longo tempo. Em 1967 fui representante dos alunos no Conselho do Instituto Central de Letras (o conselho funcionava como uma espécie de congregação, menos solene), e em 1968, fui presidente do Diretório Acadêmico Carlos Drummond de Andrade. Foram trabalhos feitos com vontade, tarefas em que aprendi muito e que me aproximaram bastante dos problemas da universidade brasileira.

Também em 1966 comecei a trabalhar num emprego ligado, de certa forma, ao jornalismo. Fiz um teste no Diário de São Paulo e o chefe da sucursal dispôs-se a contratar-me, mas só teria condições para isso depois de alguns meses (de tão longe vem a decadência dos Diários Associados). Enquanto esperava eu poderia ir praticando, com ordenado de meio salário mínimo, no setor de divulgação do Hotel Nacional, que ele também dirigia. Dava para dispensar a mesada paterna, aceitei.

O trabalho era fácil, rápido, e deixava-me bastante tempo para estudar. Consistia em escrever press-releases sobre o que acontecia no Hotel - na época o mais luxuoso de Brasília, e centro de sua vida social -, noticiando quem chegava, entrevistando alguma personalidade (Harry Stone, por exemplo, ou Mário Cravo Neto; ou um documentarista francês da ORTF), e anunciando um chá beneficente qualquer. Tinha uma sala para mim, fazia depressa o boletim do dia, despachava e ficava estudando. Escrevi, então, para o curso de Literatura Portuguesa, uma monografia longa, de mais de trinta páginas, sobre as ideias e a poesia de Antero de Quental. Penso que foi a minha primeira tentativa séria no ensaio.

Fiquei no Hotel uns oito meses, quase até o fim do ano. Quando o contrato com o Diário desencantou, recebi também um convite de Cyro dos Anjos, amigo de minha família, para trabalhar como monitor de sua disciplina - Teoria Literária - no Instituto de Letras. Meus interesses já estavam muito mais voltados para a Universidade, de modo que recusei o contrato, aceitei a bolsa de monitoria, e desisti de vez do jornalismo.

Devo falar desse trabalho de monitor e das minhas relações com Cyro dos Anjos, com quem colaborei durante dois anos (1967-1968). O curso de dele chamava-se "Oficina Literária”, e funcionava como um ateliê 
de escritores: os alunos compunham os textos curtos (geralmente contos e crônicas), que eram discutidos durante as aulas, sempre em forma de seminários em que todos palpitavam. Cyro procedia a uma dissecção do texto em exame, sentença por sentença, palavra por palavra. Minucioso, discutia o uso dos artigos, o efeito de um adjetivo, o significado preciso de qualquer vocábulo, a pontuação e o ritmo das frases, a estrutura geral. Eram aulas de técnica literária e estilística, animadas pelo sentimento participante de todos, que reescreviam juntos o conto ou a crônica. Não se tratava de correções, como pode parecer, mas de uma verdadeira reescritura, em que os problemas da expressão literária apareciam de modo nítido. E o gosto de Cyro dos Anjos pelo corte clássico da linguagem, que deveria ser concisa, limpa e direta. Nesse sentido aprendi muito com ele. Embora não escrevesse narrativas, apresentei também meus ensaios de crítica, que foram submetidos à mesma análise atenta para os termos repetidos, os adjetivos retóricos, os efeitos cacofônicos, as imprecisões das palavras empregadas.

Como monitor, ficava incumbido de selecionar os textos, discuti-los com os alunos fora do horário das aulas e realizar um ou outro seminário, sobre assunto teórico (passagens da Estilística da língua portuguesa, de Rodrigues Lapa, o trecho de Freud sobre a criação artística, capítulos do manual de Kayser). Fora disso, a bolsa me deixava livre para os estudos e logo passei a conviver com o pequeno grupo de monitores e instrutores do Instituto. Éramos sete pessoas, todas sentindo-se desorientadas dentro dos descaminhos de improvisação em que caíra a UnB. Por conta própria, passamos a nos reunir uma vez por semana, para seminários sobre os temas mais diversos. Alguém fazia mestrado sobre a obra de Bernardo Élis, e analisou um conto dele; outro estudava Guimarães Rosa, expôs seu plano de dissertação; mais um, interessado em Nelson Rodrigues, propunha o seu tema etc. Lembro-me de ter discutido o engajamento do artista, a propósito do discurso de Camus na recepção do prêmio Nobel, e de ter escrito e apresentado um ensaio sobre Babbitt. Isso foi em 1967. Em 68, quando nos sobrava tempo, entre uma passeata e outra, retomamos os seminários, de maneira mais espaçada e também mais centrada sobre o tema literatura e sociedade. Foi quando li o livro de Antonio Candido, cuja Formação já usávamos muito para os trabalhos dos cursos regulares. Discutimos ainda os Ensaios sobre Literatura, de Lukács, e tomei conhecimento de "dois críticos jovens", como se falava então: Roberto Schwarz e José Guilherme Merquior.

Em fins de 67, ganhei uma bolsa do Departamento de Estado dos EUA, dentro de um programa de aproximação com as lideranças estudantis. Viajamos em janeiro de 68, e em trinta dias visitamos Nova York, Washington, São Francisco e Los Angeles. Foi minha primeira (e até hoje única) viagem ao exterior. Os movimentos em defesa dos direitos civis 
dos negros e contra a guerra do Vietnã estavam no auge nas universidades americanas nessa época. Nosso grupo, formado de seis pessoas saía sempre impressionado dos contatos com os estudantes, quase todos críticos abertos da intervenção militar no sudeste asiático. Se a intenção era de aliciar, o tiro saiu (como no Vietnã mesmo) pela culatra: voltamos mais informados sobre a Guerra e mais decididamente antiimperialistas. Também o contraste da riqueza americana com a miséria brasileira nos chocaria e já conhecíamos algumas causas. Três de nós nos encontraríamos, em maio daquele ano, obrigados a convivência de uma semana nas celas da Polícia do Exército em Brasília, sob acusação de "participar do movimento estudantil" (o que admitimos todos, sem consequência jurídica, mas com outra consequência no meu caso particular: um dossiê no serviço de triagem ideológica do MEC, fonte de problemas anos mais tarde)

O ano de 1968 foi aquela correria, literal e figurada. Como presidente de Diretório Acadêmico, andei sempre perto de tudo, participando de Assembleias, comícios-relâmpagos e passeatas. Por duas vezes, em maio e em agosto, a Polícia Militar invadiu brutalmente o campus, espancando e depredando instalações. Muito Próxima do centro do poder, a UnB foi toda vida um incômodo e um alvo fácil para o governo, que sempre tentou domesticá-la. Nunca conseguiu de todo, apesar do reitor que lá está e na minha época já era "vice-rei" - como o chamávamos, por apócope. Sua penúltima proeza (antes de realizar a última, a recondução ao cargo, contra o desejo da maioria dos professores e estudantes) foi vir a São Paulo defender o ensino pago, de acordo com o governador Maluf. Essa seria a derradeira das medidas sugeridas para a Universidade Brasileira por Rudolph Atcon e Meira Mattos, cujos relatórios lemos nos "grupos de estudo" de 68, e que vimos serem aos poucos aproveitados durante todos esses anos.

Formei-me em fins de 68, bacharel e licenciado em Letras Brasileiras (equivalente ao curso de Vernáculas da FFLCH da USP). A solenidade de formatura - momento de passagem simbólica - coincidiu com a decretação do AI-5. Eu já havia decidido fazer um curso de pós-graduação em São Paulo, na área de Teoria Literária. Preparei-me durante as férias, relendo e fichando a pequena bibliografia que estava ao meu alcance.

\section{São Paulo. Pós-graduação (regime antigo). Experiência docente.}

Vim para São Paulo em 1969, disposto a permanecer aqui durante três anos, fazer o mestrado e tentar uma bolsa para o exterior. Queria estudar literatura e sociedade, aprofundando um pouquinho que havia aprendido um ano antes, e procurei o curso de Antonio Candido. Eram férias, a Faculdade estava deserta. Trouxera o telefone de Roberto Schwarz, 
mas não o encontrei também. Afinal, conseguir localizar João Alexandre Barbosa, que tinha sido professor em Brasília, até a crise de 1965. Ele teve a paciência de conversar duas horas comigo, explicando que haveria uma seleção, dando a data provável e indicando o que eu deveria fazer para inscrever-me. Ao mesmo tempo, procurei um lugar como professor do Estado, o que foi bastante difícil (tinha apenas os pontos correspondentes ao diploma). As inscrições eram feitas de escola em escola, de modo que, andando de ônibus sem conhecer São Paulo, tive de percorrer cerca de quinze ginásios localizados nos mais diversos bairros, e no prazo apertado de uma semana. Afinal, consegui vinte aulas no Ginásio Estadual do Alto da Mooca, depois Colégio Estadual Prof. Loureiro Júnior. Fui morar lá perto, no outro extremo da Cidade Universitária.

Também fui aceito e matriculei-me na pós-graduação (regime antigo), naquele mesmo ano, na área de Teoria Literária e Literatura Comparada, sob orientação de Antonio Candido. Na verdade, creio que foi a partir daí que defini de maneira mais clara um rumo intelectual e assumi de vez a profissão de professor. Chegado meio aéreo, com planos a curto prazo, fui ficando e aqui estou até hoje - são doze anos já.

No regime antigo de pós-graduação, em 1969, fiz três cursos, cada um de dois semestres: Teoria Literária A, com o Prof. Antonio Candido; Teoria e História do Cinema, com o Prof. Paulo Emílio; e Sociologia da Literatura, com o Prof. Ruy Coelho. Em 1970, fiz o quarto e último curso, Teoria Literária B, também com o Prof. Antonio Candido. Resumo abaixo o que foram esses cursos e quais os seus resultados.

Em Teoria Literária A, dada pelo Prof. Antonio Candido em 1969, fui aprovado com nota 9,0 (nove). Durante o primeiro semestre o curso versou sobre a "Expressão literária dos fatos políticos (Shakespeare) ", e no segundo semestre sobre "O estudo analítico do poema". Fiz dois trabalhos escritos. O primeiro foi uma análise da peça A tragédia do Rei Ricardo III, de W. Shakespeare, na qual procurei estudar a estrutura da ação, relacionando seu significado com as estruturas metafóricas subjacentes às falas das personagens. O segundo trabalho foi uma "Leitura de 'Campo de flores", em que procurei examinar os vários estratos do poema de Drummond a partir de uma observação de W. Kayser sobre a natureza do lírico (retirada da Estética de Hegel). Esse ensaio foi posteriormente publicada na Revista do Instituto de Estudos Brasileiros da USP (n. 11, 1972).

Em Teoria e História do cinema, dado pelo Prof. Paulo Emílio (1969), fui aprovado com nota 7,0 (sete). No primeiro semestre estudamos "O expressionismo alemão: cinema e literatura"; no segundo semestre vimos "Os primitivos" do cinema europeu e americano. Houve também dois trabalhos escritos: elaborei um roteiro para curta-metragem (com a finalidade de demonstrar conhecimento básico das técnicas de filmagem) e um Relatório Final sobre as atividades desenvolvidas durante os dois 
semestres (comentários aos filmes exibidos, resenhas da bibliografia lida, sumário dos debates havidos em aula). Nesse relatório procurei destacar e explicitar aquilo que tinha sido o fio condutor do curso, o nascimento e a evolução da linguagem cinematográfica, desde Lumière e Mèlies a Griffith, Gance, Stroheim, Seastrom, Clair, o cinema expressionista alemão e o seu desenvolvimento posterior.

Em Sociologia da Literatura, dada pelo Prof. Ruy Coelho (1969), fui aprovado com nota 9,0 (nove). Durante os dois semestres foram examinadas alguns textos teóricos que focalizavam as relações entre literatura e sociedade, ao mesmo tempo que procurava-se aplicar os conceitos em Grande sertão: veredas. Além da participação nos seminários, redigi um trabalho em que utilizei as concepções de G. Lukács (A teoria do romance) e L. Goldmann (Sociologia do romance), na análise de um livro de Cyro dos Anjos, $O$ amanuense Belmiro. Esse ensaio, intitulado "À sombra das moças em flor", foi publicado depois na Revista do Livro (n. 42, 1970).

Finalmente em 1970, fiz Teoria Literária B, também com o Prof. Antonio Candido, e fui aprovado com nota 9,0 (nove). O curso foi sobre as “Teorias Críticas Contemporâneas". No primeiro semestre estudamos o new criticism e o formalismo russo (fiz um seminário sobre o texto de Eikhenbaum - "A teoria do método formal"); no segundo semestre abordamos as várias correntes estruturalistas. $\mathrm{O}$ trabalho final consistiu na elaboração de um ensaio em que procurei expor, comparativamente, as ideias de T. Todorov e R. Barthes sobre os problemas teóricos colocados pela narrativa.

Durante esse tempo trabalhei no Ginásio Estadual do Alto da Mooca, lecionando para alunos do primeiro grau, no curso noturno.

Foi a minha primeira experiência docente (fora da monitoria da UnB) - e não foi agradável. O clima na escola era de autoritarismo e submissão, o nível geral era muito baixo (falo de professores e alunos) e o resultado era desanimador.

Por sorte, já em fins de 1970, fui convidado por Ligia Chiappini Moraes Leite para trabalhar, com ela e José Miguel Wisnik, no curso Equipe Vestibulares. Eles davam aulas de análise Literária, preparando os alunos para a prova específica de comentário de texto, que havia no vestibular de Letras. Minha função seria de auxiliá-los, corrigindo os trabalhos dos alunos e dando plantões de atendimento para os que apresentassem problemas. Essa foi uma atividade gostosa. Corrigir as redações tomava tempo (eram cerca de cem por semana), mas transformei os plantões de atendimento em aulas a que todos assistiam. Analisava contos e poemas, e pude ir praticando o que aprendi na Faculdade. Permaneci na equipe até o fim de 1971, quando tiraram a prova específica do vestibular. Do ginásio eu saíra no começo de 1971, ao mesmo tempo em que iniciava as pesquisas para a dissertação de mestrado. 


\section{Mestrado. Aulas na Faculdade. Início do doutoramento. Artigos.}

No início de 1971 foi implantado o novo regime de pós-graduação na FFLCH da USP. Inscrevi-me para o mestrado, na área de Teoria Literária e Literatura Comparada e sob orientação do Prof. Antonio Candido. Por sugestão dele, escrevi um projeto de pesquisa intitulado "Aspectos da crítica literária no decênio de 30, em São Paulo e no Rio de Janeiro", apresentei-o à Fundação de Amparo à pesquisa do Estado de São Paulo (Fapesp) e obtive uma bolsa de aperfeiçoamento para o período de março /1971 a fevereiro /1973.

Realizei o trabalho dentro desse prazo. Parti de uma concepção do desenvolvimento do Modernismo (parcialmente tomada a Antonio Candido, parcialmente à revisão feita pelos poetas concretos), que o compreendia como dividido em duas fases: a "fase heroica", preocupada com os experimentos de linguagem e a ruptura dos velhos códigos, e a fase posterior a 30, marcada pela luta político-ideológica. Nesse quadro, procurei situar a obra de quatro críticos (Agripino Grieco, Tristão de Ataíde, Mário de Andrade e Otávio de Faria), tentando verificar até que ponto guardaram eles as lições do Modernismo, até que ponto compreenderam e aceitaram o conceito de literatura como linguagem, até que pontos foram capazes de equilibrar a necessidade de realização estética e a necessidade de participação político ideológica. A tensão entre o que chamei de projeto estético do Modernismo (a consciência da linguagem e a ruptura com as formas tradicionais de representação literária) e o que denominei projeto ideológico (a proposição de participar socialmente através da literatura) foi o fulcro do trabalho.

A base teórica dessa dissertação foi, evidentemente, retirada das leituras feitas durante os vários cursos realizados ao longo de quatro anos (69-72), com predominância absoluta dos autores formalistas e estruturalistas. A concepção da "literatura como linguagem", bem como a concepção de "linguagem literária" (e outros conceitos derivados desses: "série literária", "metalinguagem", "evolução literária" etc.) foram tirados daí. Embora aplicados de modo não muito rígido, marcaram e dataram com clareza o trabalho, e, se permitiram sua realização, impuseram-lhe também limitações grandes. Uma delas (apontado por membro da banca examinadora) foi a superficialidade com que tratei o conceito de "ideologia", e por extensão - no plano teórico - os aspectos sociais da literatura e da "linguagem literária".

Defendida em Maio de 1973, perante a banca composta pelos professores Drs. Antonio Candido de Mello e Souza (orientador), Telê Porto Ancona lopez e Davi Arrigucci Jr., a dissertação foi aprovada, com grau 10,0 (dez). Sua introdução, com o título "Estética e ideologia: o 
Modernismo em 1930", foi publicada na revista Argumento (Rio de Janeiro, Paz e Terra, a. I, n. 2, 1973). O trabalho completo foi editado no ano seguinte, com o título 1930: a crítica e o Modernismo (São Paulo, Duas Cidades, 1974).

No "regime novo" de pós-graduação fiz mais quatro cursos, necessários à complementação dos créditos do mestrado e doutoramento. Foram os seguintes.

Com o Prof. Antonio Candido, no primeiro semestre de 1971, estudei Métodos de Trabalho em Teoria Literária, tendo obtido nível A e 3 (três) créditos. O curso enfocou inicialmente noções de ecdótica (crítica textual), passando em seguida a abordar os princípios gerais de várias escolas críticas, da Antiguidade ao estruturalismo: as contribuições de Platão e Aristóteles para a compreensão da natureza e da estrutura da obra literária; a abordagem positivista e naturalista da literatura, o pensamento crítico de Taine; os postulados fundamentais do new criticism; o estruturalismo, a poética e a crítica, os enfoques sociais e históricos de literatura, a crítica temática e a psicocrítica.

Apesar de considerado como "Instrumental", esse curso foi importante principalmente por ter oferecido uma visão sintética e comparativa de diferentes posições teóricas frente ao fenômeno literário.

No segundo semestre de 1971 fiz "Estética do Modernismo", com a Profa. Gilda de Mello e Souza, tendo obtido nível A e 10 (dez) créditos. Estudamos as poéticas das vanguardas do começo do século (cubismo, expressionismo, futurismo, surrealismo), visando à compreensão das direções estéticas do Modernismo no Brasil, visto em suas ligações com as origens cosmopolitas e em sua originalidade de criação "brasileira".

O seminário e o trabalho escrito que fiz nesse curso constituíram depois o núcleo da minha dissertação de mestrado, que pôde ser articulada a partir das informações e das discussões ali realizadas. Estudei o "Prefácio interessantíssimo" e A escrava que não é Isaura, e escrevi um ensaio curto ("Poética explícita e poética implícita"), que depois, desenvolvido, transformou-se em um dos capítulos da dissertação de mestrado ("A consciência da linguagem"), tentativa de compreensão das ideias estéticas de Mário de Andrade. Também as linhas principais de minha tese de doutoramento, escrita oito anos depois, seriam inspiradas diretamente pelas aulas de D. Gilda, que ensinou-me quase tudo que sei sobre a poesia de Mário de Andrade.

No segundo semestre de 1972, fiz o curso de "Filosofia da ciência política", com a Profa. Maria Sílvia de Carvalho Franco, tendo obtido nível A e 10 (dez) créditos. O tema central foi a formação de ideologias e sua análise. Para mim, foi proveitoso principalmente pela leitura e discussão, em sucessivos seminários de A ideologia alemã e de alguns capítulos de $O$ capital. 
Por fim, também no segundo semestre de 1972, acompanhei as aulas do Prof. Alfredo Bosi sobre "A poesia de Jorge Lima", o curso foi principalmente uma reflexão sobre as teorias da linguagem poética. Buscou-se articular uma série de textos teóricos a poemas do autor, testando-se assim a validade e o alcance das concepções estruturalistas (e também de outras correntes críticas). Escrevi uma análise do poema "Rei é Oxalá, rainha é Iemanjá", baseado em texto de Jolkóvski ("Da amplificação") e na definição das funções da linguagem, de Jakobson.

Tive de abandonar o curso pela metade (estava redigindo, em fase final, a dissertação de mestrado), mas posteriormente li toda a bibliografia indicada para os seminários. Registro aqui esse curso porque acredito que ele foi extremamente importante para a minha formação teórica, no que se relaciona à compreensão da linguagem poética. Ao mesmo tempo que tomei conhecimento de vários autores e textos de linha estruturalista, aprendi a criticá-los e a perceber suas limitações. Entre os livros e ensaios lidos destaco os seguintes: Teses de Círculo Linguístico de Praga, S. Levin (Linguistic Structures in Poetry), Ó. Brik "Ritmo e sintaxe", E. Sapir ("Os fundamentos musicais do verso"), M. Riffatterre (Essais de stylistique structurale), Jolkóvski ("Dell' amplificazione"), revista Change, n. 6, Greimas (Sémantique structurale), Bühler (Teoría del linguaje, trechos), Roman Jakobson, Jean Cohen (Structure du language poétique), Hegel (poesia) e Adorno ("Lírica y Sociedad").

Além desses cursos, fiz também em 1973, uma série de leituras para os seminários de doutoramento, realizados sob orientação do prof. Antonio Candido. O tema foi "Literatura e sociedade", e entre os textos lidos e discutidos destaco os seguintes: G. Plekhánov, Sociologia da arte, Roger Bastide, Arte e sociedade, L. Trótski, Literatura e revolução; C. Caudwell, Ilusión y realidad; G. Lukács, Ensaios sobre literatura; Marxismo e Teoria da Literatura; L. Goldmann, Dialética e Ciências Humanas I, J. Fréville (org.), trechos escolhidos sobre literatura e arte; T. W. Adorno, Notas de Literatura, Prismas; W. Benjamin, Iluminaciones 1 e 2; E. Auerbach, Mimesis.

Essas leituras contribuíram muito para a superação, a que atrás me referi, das posições teóricas assumidas por ocasião da dissertação de mestrado. Além disso, a partir dos seminários, o Prof. Antonio Candido organizou um simpósio, que se realizou em julho de 1973, na Reunião Anual da SBPC, no Rio de Janeiro, e do qual participei.

Mas voltemos um pouco atrás no tempo. Ainda no segundo semestre de 1971 comecei a lecionar na Faculdade, junto ao curso de Introdução aos Estudos Literários. No começo, trabalhava em dupla com Davi Arrigucci Júnior: ele dava aulas expositivas e eu me encarregava dos seminários, orientando os alunos, fazendo as análises de contos e poemas junto com eles, assistindo e avaliando as apresentações. A partir de 1972 assumi 
sozinho duas turmas, e assim foi durante dois anos. Era uma espécie de "instrutor voluntário" (embora oficialmente a Faculdade não designasse mais ninguém por esse título), trabalhando sem vínculo empregatício e sem nada a receber. Exceto, naturalmente, a experiência didática, que foi muito grande e recompensadora, e a convivência com os professores da área, também fecunda e estimulante. Mas em fins de 1973, como não houvesse verba para contratar-me, decidi parar com as aulas e dedicar-me apenas à tese de doutoramento. Devo falar agora sobre ela.

Em 1973 apresentei um projeto de pesquisa à Fapesp, e obtive uma bolsa de doutoramento que se estendeu por dois anos (março de 1973 / fevereiro 1975). O projeto intitulava-se "A poesia de Mário de Andrade: estudo de algumas tendências estéticas e ideológicas". Era um prolongamento natural da minha dissertação de mestrado, e uma maneira de aprofundar o meu conhecimento do Modernismo. Partia da hipótese básica de que a variedade da poesia de Mário refletia as linhas-de-força da nossa literatura contemporânea. Do psicologismo e da destruição da linguagem, nos primeiros livros, ao esforço construtivo e a participação política dos últimos, passando pela poesia do nacionalismo "pau-brasil" e pelas imagens herméticas de certas composições, a obra do poeta espelharia, mais do que preocupações artísticas individuais, toda uma agitação intelectual que se processou no Brasil durante cerca de vinte e cinco anos.

A partir daí propunha-me a estudar as Poesias completas em três direções principais: (a) uma análise interna dos poemas e dos procedimentos utilizados; (b) uma ligação com as estéticas modernistas em plano nacional e universal; (c) uma ligação a ser estabelecida com aspectos da sociedade brasileira. O que me interessava era explicar a diversidade da poesia de Mário, entendendo-a como consequência necessária de uma série de fatores determinantes, estéticos e sociais. Mas o plano era excessivamente ambicioso. Trabalhei nele durante os dois anos de bolsa, e avancei um pouco, mas estava longe de conseguir realizá-lo. No começo de 1975, por motivos de ordem pessoal, tive de desistir do chamado "ano de redação" (a prorrogação que a Fapesp às vezes concede), abandonar temporariamente a tese e dedicar-me a outras coisas.

Por um semestre, voltei a lecionar no ensino público, desta vez num ginásio estadual da periferia de São Paulo, no bairro Jardim Santo Onofre, no limite dos municípios de Taboão da Serra e Embu. A situação era pior do que nos tempos do Alto da Mooca: além de autoritarismo e do baixo nível geral, havia ainda a pobreza terrível do lugar e dos alunos.

Fui salvo - a palavra é esta mesmo - de novo por Ligia Chiappini, que me convidou para dar um curso de especialização em Teoria Literária, nas Faculdades Integradas Princesa Isabel, em Moema. Foi outra experiência interessante. Até então só lecionara para vestibulandos e 
alunos do primeiro ano, ensinando o mais elementar da teoria. Em nível de especialização poderia desenvolver melhor a matéria, e foi o que eu fiz. Retomei os livros lidos no curso de pós-graduação e montei um programa de análise da narrativa, baseado sobre a estilística, o formalismo russo e o estruturalismo. Previa, para o segundo semestre, a passagem para as teorias sociológicas da narrativa (Lukács, Goldmann, Adorno e Benjamin), mais fui trabalhar na Unicamp e interrompi o curso.

Entre 1974 e 1975 escrevi também alguns artigos, que foram publicados. Em “O mundo à revelia”, estudo do romance S. Bernardo, de Graciliano Ramos (publicado como prefácio do livro, São Paulo, Martins, 1974 - e também nas edições seguintes), tentei mostrar a homologia existente entre estrutura literária (principalmente as estruturas de ação e personagem) e estrutura social (a estrutura da reificação, característica do capitalismo). Em "As imagens do desejo", estudo de Senhora, de José de Alencar (São Paulo, Ática, 1975), procurei analisar o estilo e o enredo do livro como deslocamentos da "estória romanesca", em conflito com a forma do romance. Baseava-me nas ideias de Northrop Fyre (Anatomia da crítica), e buscava uma alternativa para a análise do meso livro feita por Roberto Schwarz (ver Ao vencedor as batatas, São Paulo, Duas Cidades, 1977). Explicitaria isso três anos depois, em resenha crítica que fiz do livro de Roberto, publicada com o título "Batatas \& desejos", em ficção em debate e outros temas (São Paulo/Campinas, Duas Cidades/Unicamp, 1979).

Em 1975, escreveria ainda: "Ontem e hoje: a tradição do impasse", sobre o livro A tradição do impasse, de João Alexandre Barbosa (resenha publicada em Debate e Crítica, São Paulo, Hucitec, n. 6, 1975); "Corda bamba", prefácio ao romance Ora pro nobis, de Flávio Aguiar (São Paulo, Ática, 1975); e "Simulação e personalidade", um estudo sobre Iaiá Garcia, de Machado de Assis (São Paulo, Ática, 1977).

Para completar a lista de minhas publicações, devo citar ainda as seguintes críticas, publicadas em jornais: "A respeito de Ralfo, farsante" (movimento 8 set. 75), sobre o romance Confissões de Ralfo, de Sérgio Sant'Anna; "Fragmentos da pré-história" (Movimento, 8 dez. 75), sobre o romance Zero, de Ignácio de Loyola Brandão; "Os contos vivos de Scliar" (movimento, 2 maio 77), sobre A balada do falso Messias, de Moacyr Scliar; "Uma alegre redescoberta do Brasil" (Gazeta Mercantil, 27 maio 77), sobre Galvez, imperador do Acre, de Márcio Souza; e "Vaidades e desprezos de Francis" (Gazeta Mercantil, 30 set. 77), sobre Cabeça de papel, de Paulo Francis (o título original do meu artigo, mudado não sei por quê, era "Retrato sob o poder").

\section{Unicamp. USP. Doutoramento Projetos atuais.}


Em 1975, fui convidado pelo prof. Antonio Candido para integrar a equipe inicial de Teoria Literária, que ele formava na Universidade de Campinas. Em julho estava contratado e começando a trabalhar. Havia já na Unicamp um bacharelado em Linguística, que não reunia condições para ser formalmente reconhecido pelo Conselho Federal de Educação, por não se enquadrar em nenhum dos currículos previstos pela lei. Nossa tarefa era a de adaptar os alunos bacharelados, ou em vias de se formarem, a um apertado currículo de Letras, com o número mínimo de horas exigido em Literatura Portuguesa, Literatura Brasileira e Teoria Literária.

Meu primeiro curso foi de Literatura Brasileira, e estava centrado sobre o romance de José de Alencar e de Machado de Assis. Parti das observações de Antonio Candido (na Formação) a respeito da continuidade entre os dois grandes escritores. Analisei Alencar como ligado ao polo da representação poética da realidade, embora em tensão com o realismo e a observação social. E analisei Machado como autor situado no polo da observação e do realismo, embora em tensão com a ironia e o dialogismo carnavalizado. Serviram de exemplos O guarani, Senhora, Memórias póstumas de Brás Cubas e Quincas Borba. Misturei Antonio Candido, Fyre, Bakhtin, Alfredo Bosi e Roberto Schwarz. O gosto me parecia bom.

O grande problema da Unicamp era a burocracia, ou melhor, achar quem se incumbisse dessas tarefas abomináveis, indispensáveis. Assumi boa parte delas, e durante, um bom tempo "respondi" pelo conjunto de Teoria Literária. O desgaste foi terrível e não o desejo a ninguém.

Agradável foi compor o currículo da futura graduação em Letras. Enquanto os doutores do grupo se incumbiam de montar o curso de pósgraduação, prioritário, os mestres Adelia Bezerra de Meneses Bolle, José Miguel Wisnik e eu montávamos um anteprojeto para o curso de graduação. José Miguel tinha ideias novas e eu tentava enquadrá-las nas exigências do CFE e Adelia funcionava como elemento de junção entre os dois extremos. Contávamos com a assessoria de Haquira Osakabe, especialista em equilíbrio. Chegamos a um projeto que sem modéstia considero ótimo, mesmo com as mudanças que sofreu depois, em virtude de vários outros interesses cruzados.

O ponto alto desse estágio da Unicamp foi a criação do Instituto de Estudos da Linguagem, dirigida por Antonio Candido. Mas nessa altura eu já tinha retomado os trabalhos do doutoramento, e estava envolvido neles. Além disso, em 1978, fora finalmente contratado pela USP, junto à disciplina de Teoria Literária e Literatura Comparada, depois de uma luta contra o misterioso arquivamento do meu processo de contratação - luta também dirigida por Antonio Candido, e da qual participaram (do nosso lado) vários docentes da Universidade e da FFLCH. Assim, fui me afastando aos poucos da Unicamp, e em maio de 1979, quando obtive o 
RDIDP na USP, desliguei-me completamente. Trabalhara lá três anos e onze meses (julho de 1975 / maio de 1979).

Desde 1976 retomara a pesquisa para a tese de doutoramento. Minha grande dificuldade era conciliar as teorias sobre a linguagem poética com a sociologia da literatura. Imaginei que um meio de contornar o problema pudesse ser o estudo das imagens presentes na poesia de Mário, e para isso fiz novas leituras: Maud Bodkin, Bachelard, Jung, Freud, Eliade, Cassirer, Norman Brown, Paul Ricoeur. Pensei que as teorias "interpretativas" (seja partindo da análise do mito, seja partindo da psicanálise) poderiam ajudar a resolver o impasse, já que elas contêm ao mesmo tempo uma teoria da linguagem e uma teoria da sociedade.

Cheguei assim ao novo plano. Baseado no ensaio de Anatol Rosenfeld ("Mário e o cabotinismo"), procurei examinar a produção do poeta como um jogo de máscaras, sucessivamente usadas e descartadas, numa trilha que ia em busca da auto-identidade e da identidade cultural do país. Tentei localizar as várias "maneiras" do escritor no contexto histórico em que elas nasceram, vendo-as como respostas à interiorização de conflitos pessoais e sociais.

Num primeiro capítulo, intitulado "Pequena introdução às máscaras", ensaiei classificá-las e explicá-las: vi a máscara do "trovador arlequinal", representante de um momento cosmopolita de industrialização e urbanização do país; depois a face do "poeta aplicado", dedicando-se ao folclore e ao levantamento da cultura nacional, no mesmo instante em que boa parte da sociedade voltava-se para o interior brasileiro (é a mesma época da Coluna Prestes, bom símbolo no plano político e social); em seguida vinha a tentativa da "unidade na diversidade", esforço de síntese e superação de todo o Modernismo, presente em Remate de males, de 1930, mesmo ano da revolução; após, os poemas de A costela do Grão Cão e Livro azul, o "espelho sem reflexo", momento de crise individual que corresponde também à crise de hegemonia política enfrentada pela burguesia, logo depois da Revolução de Trinta; por fim, apresentava-se o "poeta político", já capaz de aprender a luta de classes, num instante em que a burguesia resolvera a sua crise pela traição aos princípios, instaurando a ditadura.

Depois de traçar esse quadro, escolhi uma das máscaras, a que me parecia problemática, e dispus-me a examiná-la em detalhe. A escolha recaiu sobre as imagens que compunham o momento de crise, em que a identidade do indivíduo e do país pareciam cada vez mais perdidas - o "espelho sem reflexo".

Li detidamente os textos de A costela do Grão Cão. Descobri, primeiro, um arquétipo (a "viagem na noite") e um mythos latente, desenvolvendose em quatro fases: o mito da procura, dividido em conflito, paixão, despedaçamento e reconhecimento. Constatei que as composições 
detinham-se no despedaçamento, indicativo da personalidade dividida e perdida, da face que não se refletia em espelho algum. Examinei a linguagem da ironia, os símbolos demoníacos que dominavam os poemas. Para entendê-los, recorri a base da interpretação psicanalítica, à comparação intertextual e ao confronto com o mito. A mesma abordagem foi repetida depois, no Livro azul, com a diferença que as imagens situavam-se agora no plano apocalíptico, de revelação: tentando sair do dilaceramento, o poeta idealizava um mundo sem conflito, onde a realidade perdia seus contornos e o desejo expandia-se, dominando tudo.

A aproximação aos poemas foi feita (quase) sempre em três níveis: primeiro, procurava descrevê-los como estruturas de palavras; depois, buscava traduzi-los em outra linguagem, o discurso da interpretação; por fim, tentava explicá-los, relacionando as características formais e os significados descobertos ao tipo de sociedade em que vivemos ou as conjunturas específicas enfrentadas pelo poeta. Os poemas foram analisados em sua forma estética e enquanto expressão das tensões do indivíduo e da sociedade.

Com o título "Figuração da intimidade (contribuição ao estudo das imagens na poesia de Mário de Andrade)", a tese foi defendida em maio de 1980, tendo sido aprovada com nota 10,0 (dez). Compuseram a banca os professores Drs. Antonio Candido de Mello e Souza (orientador), Marlyse Meyer, Iumna Maria Simon, Modesto Carone Neto e Davi Arrigucci Jr.

Do projeto inicial apresentado à Fapesp, em 1973, restaram alguns ângulos sem qualquer abordagem mais profunda. A partir da defesa comecei a trabalhar em um deles: o problema da arte "nacional" e "popular". Até o final do ano pretendo escrever um ensaio sobre assunto.

E tenho já o tema para ser pesquisado depois disso. Desejo fazer um estudo comparativo entre as vanguardas históricas europeias e o Modernismo brasileiro, do ponto de vista da representação da "modernidade". Inspiro-me nos estudos de Walter Benjamin sobre Baudelaire, e quero examinar como certos temas e traços estilísticos, ligados a cidade cosmopolita, aparecem nas vanguardas francesas do início do século e nos modernistas brasileiros. Para isso, estou no momento planejando passar o ano de 1981 em Paris, estudando os movimentos vanguardistas.

São Paulo, 19 de outubro de 1980. 
João Luiz Lafetá graduou-se em Letras pela Universidade de Brasília. Sob orientação de Antonio Candido, na Universidade de São Paulo, concluiu o mestrado em 1973, com a dissertação sobre a crítica e o Modernismo, e obteve o título de doutor em 1980, com a tese sobre a lírica de Mário de Andrade. Lecionou na USP como instrutor voluntário, sem vínculo empregatício e sem remuneração, junto à disciplina Introdução aos Estudos Literários. Durante os anos de chumbo, escreveu diversos artigos para o jornal Movimento, um dos órgãos alternativos de resistência à ditadura. Foi professor de Teoria Literária e Literatura Comparada da Faculdade de Filosofia, Letras e Ciências Humanas da USP, professor de Teoria Literária na Universidade Estadual de Campinas e professor visitante de Literatura Brasileira no Lateinamerika, Instituto na Universidade de Berlim. Segue um nome fundamental da crítica literária brasileira, com estudos da obra crítica e poética de Mário de Andrade, ensaios sobre a poesia de Ferreira Gullar, sobre os romances de Graciliano Ramos e sobre os contos de Rubem Fonseca. Faleceu em 19 de janeiro de 1996. 